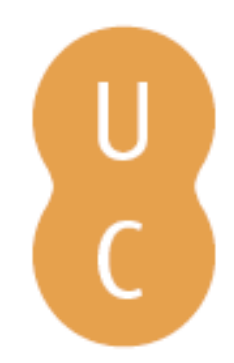

\title{
nommalina
}

The relationship between time perspective and death attitude in women patients with type II diabetes
Autor(es):
Nozari, Masoumeh; Dousti, Yarali; Ahmad, Roya Raoufi
Publicado por: Imprensa da Universidade de Coimbra
URL
persistente:
URI:http://hdl.handle.net/10316.2/38621
DOI:
DOI:http://dx.doi.org/10.14195/978-989-26-0775-7_17
Accessed : $\quad$ 26-Apr-2023 15:54:40

A navegação consulta e descarregamento dos títulos inseridos nas Bibliotecas Digitais UC Digitalis, UC Pombalina e UC Impactum, pressupõem a aceitação plena e sem reservas dos Termos e Condições de Uso destas Bibliotecas Digitais, disponíveis em https://digitalis.uc.pt/pt-pt/termos.

Conforme exposto nos referidos Termos e Condições de Uso, o descarregamento de títulos de acesso restrito requer uma licença válida de autorização devendo o utilizador aceder ao(s) documento(s) a partir de um endereço de IP da instituição detentora da supramencionada licença.

Ao utilizador é apenas permitido o descarregamento para uso pessoal, pelo que o emprego do(s) título(s) descarregado(s) para outro fim, designadamente comercial, carece de autorização do respetivo autor ou editor da obra.

Na medida em que todas as obras da UC Digitalis se encontram protegidas pelo Código do Direito de Autor e Direitos Conexos e demais legislação aplicável, toda a cópia, parcial ou total, deste documento, nos casos em que é legalmente admitida, deverá conter ou fazer-se acompanhar por este aviso.

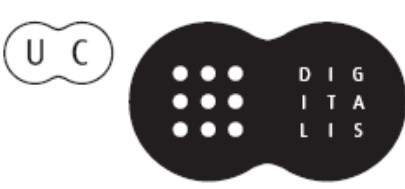




\section{INTERNATIONAL \\ STUDIES IN TIME \\ PERSPECTIVE}

MARIA PAULA PAIXÃO

JOSÉ TOMÁS DA SILVA

(COORD.)

VICTOR ORTUÑO

PEDRO CORDEIRO

(EDITORS)

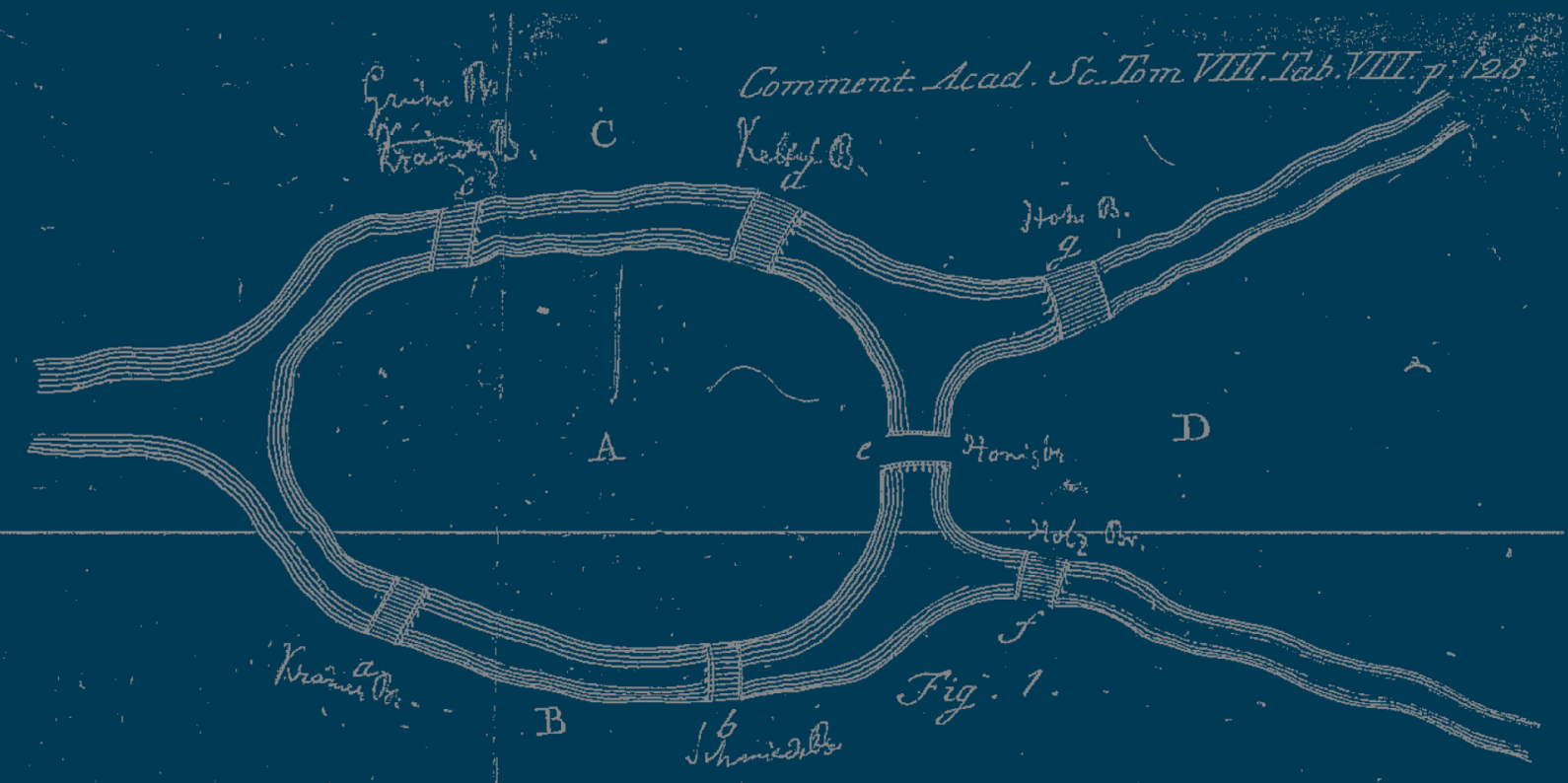

IMPRENSA DA

UNIVERSIDADE

DE COIMBRA

COIMBRA

UNIVERSITY

PRESS 
CHAPTER 17

\title{
THE RELATIONSHIP BETWEEN TIME PERSPECTIVE AND DEATH ATTITUDE IN WOMEN PATIENTS WITH TYPE II DIABETES
}

\author{
Masoumeh Nozari \\ Yarali Dousti \\ Roya Raoufi Ahmad \\ Islamic Azad University, Sari Branch, Iran \\ roya.nozari@gmail.com \\ raoufi.rar1973@yahoo.com
}

\begin{abstract}
Aвstract: Time perspective helps to give order and meaning to events, and is also used in encoding, storing and recalling experienced events. The aim of the study was to investigate the relationship between time perspective and death attitude in diabetic women patients. In a cross-sectional design study, 100 outpatients were selected by sampling at hand. Data were collected through two questionnaires including (ZTPI-56) and (DAPR-32). Results revealed a significant positive correlation between different time perspectives and death attitudes. Past-Positive orientation is connected with the view of death as a natural phenomenon and approach acceptance. Past-Negative orientation is connected with the escape acceptance, and also with fear of death and avoidance. Present-Hedonistic orientation is connected with escape and avoidance. Present-Fatalistic orientation is connected with natural acceptance. Future orientation is connected with the view of approach and avoidance. According to these findings, diabetic women patients with past-negative and presentfatalistic orientations have a more negative view of death.
\end{abstract}

Keywords: time perspective, death attitude, patients with type II diabetes.

\section{INTRODUCTION}

Time perspective (TP) is used in encoding, storing, and recalling experiences; in sensing, feeling, and being; and in shaping expectations, goals, contingencies and in imagining scenarios. Zimbardo \& Boyd (2008) believe that time perspective is often a non-conscious personal attitude that each of us holds toward time and the process whereby the continual flow of existence is bundled into time categories that help to give order, coherence, and meaning to our lives. For example, our thoughts about the past, the present, and the future may be positive or negative, happy or sad, hopeful or fearful.

Many basic psychological processes rely on some aspect of time, such as habituation, conditioning, memory, reinforcement contingencies, self-efficacy, anticipation, violation of expectation, evolutionary adaptive, guilt, depression and anxiety, to name but a few. Even fundamental distinctions between cognition and emotions are reconcilable within the framework provided by a temporally-based theory in which emotions are cast as being evolutionarily more primal for immediate responding, whereas cognitions are cast as later 
adaptations for planning and reflective responding (Zimbardo \& Boyd, 1999). Cognitive processes involve reconstructing the past and constructing the future, thus influencing current decision making and behavior. One's beliefs about negative past experiences and a life path predestined and uninfluenced by individual actions have been positively associated with depression and trait anxiety, and negatively associated with self-esteem. A present-time perspective has been positively related to risk-taking behaviors and substance use (Anagnostopoulos \& Griva, 2012).

Results of research showed the predicting role of TP in preventing healthy \& unhealthy behaviors (Fieulaine \& Martinez, 2009; Zambianchi \& Ricci Bitti, 2008; Zambianchi, Ricci Bitti \& Paola, 2010). Both approach and avoiding motivations increase as the future goal/event is approached in time and it influences the performance level of pupils differently (Bjornebekk \& Gjesme, 2009). But if a certain time perspective starts to dominate an individual's view of time to the extent that it excludes or minimizes the others, it may become dysfunctional. In an optimally balanced time perspective, the past, present and future components blend and flexibly engage, depending on a situation's demands and our needs and values (Osin, Boniwell, Iwley \& Ivanchenko, 2009).

The threat of death is the most fundamental and important source of adaptive and maladaptive psychological structures like high and low self-esteem (Mohammadi, Ghorbani \& Abdollahi, 2010). As an existential crisis, death anxiety may create suffering and impact quality of life (Sherman, Norman \& Mcshenny, 2010).

Continuous exposure to death can have adverse effects on physical health and mental well-being. Some of the effects found to be associated with higher levels of death anxiety include general anxiety, depression, discrepancy between self and ideal self, negative selfattitude, and neuroticism (Harrawood, White \& Benshoff, 2008-2009). Studies suggest that although illness alone may arouse death concerns in some people, the degree of death anxiety triggered by deteriorating health is a function of both interpersonal factors (social support) and personal resource (coping styles and religious beliefs), rather than illness per se (Neimeyer, Wittkawski \& Mosen, 2004).

Studies showed that an improvement in perception of the meaningfulness of life in four categories: expanded viewpoint; sadness about death; treating life sincerely; and instilling hope in life, was associated with interaction and self-reflection (Hwang, Chen \& Lin, 2005). Future time perspective associated with it leads to a positive outlook on death (Neimeyer et al., 2004).

The researchers in this study investigated the relationship between time perspective and death attitude profile in women patients with diabetes type II.

\section{Method}

In a cross-sectional design study, 100 female outpatients with diabetes type II from Imam Hospital clinics in Sari/Iran, were selected by sampling at hand (2011-2012). Data were collected through two questionnaires including the Zimbardo Time Perspective Inventory (ZTPI-56) and Death Attitude Profile-Revised (DAPR). Half of the cases filled in the Time Perspective Inventory first and Death Attitude Profile-Revised next, and the other half did the reverse. Ages ranged from 18-78 years $(\mathrm{M}=48.21, \mathrm{SD}=12.01)$. 


\section{Measures}

Time Perspective Inventory (ZTPI). The Zimbardo Time Perspective Inventory (Zimbardo \& Boyd, 1999) is a 56-item measure consisting of five subscales, each including 9-15 items. Participants respond to statements using a 5-point Likert scale ( $1=$ very uncharacteristic; $5=$ very characteristic). Its developer reported internal consistency estimates for subscale scores based on Cronbach's alpha coefficients ranging from .74 to .82. Test-retest reliabilities (over a 4-week period) of the five subscales ranged from .70 to .80 .

Death Attitude Profile-Revised (DAPR). The death attitude profile-revised inventory is a 32-item measure consisting of five subscales (Fear, Avoidance, Neutral Acceptance, Approach, and Escape Acceptance). Participants respond to statements using a 7-point Likert scale. Its developer reported internal consistency estimates for subscale scores based on Cronbach's alpha coefficients ranging from 0.65 to 0.97 .

\section{RESULTS}

Correlation coefficients showed a significant positive correlation between different time perspectives and death attitudes. Past-Positive orientation is connected with the view of death as a natural acceptance and approach acceptance. Past-Negative orientation is connected with escape acceptance, also fear of death and avoidance. Present-Hedonistic orientation has a positive correlation with escape and avoidance acceptance. PresentFatalistic orientation is connected with natural acceptance. In addition, Future orientation is connected with the view of approach and avoidance acceptance (Table 1).

\section{Discussion}

The findings showed that there is a positive and significant relation between fear of death and escape acceptance and death avoidance components with past-negative (PN) time perspective. Studies showed that negative perception of the past reflects an unhappy view toward the past and it is associated with depression, trait anxiety and self-reported unhappiness (Zimbardo \& Boyd, 1999; Anagnostopoulos \& Griva, 2012). In additional, higher levels of depression and anxiety were also predicted by $\mathrm{PN}$ in individuals diagnosed with chronic diseases such as diabetes (Anagnostopoulos \& Griva, 2012). Death is feared for different reasons. The loss of self, the unknown beyond death, pain and suffering, lost opportunity for atonement and salvation are just some of the sources of fear of death (Neimeyer, 1994).

Based on the findings of different studies, it is assumed that negative obsessive rumination with past memories leads to activating negative attitudes toward death.

Positive Past (PP) showed positive correlations with natural and approach acceptance. In natural acceptance, a person believes that death as a reality is neither feared nor welcomed. Whereas in approach acceptance, a person believes in death as a gateway to a happy life hereafter (Neimeyer, 1994). So, this finding supported studies which showed PP as related to a strong sense of self-esteem and happiness, and low levels of depression and anxiety 
(Anagnostopoulos \& Griva, 2012). Present-Hedonistic (PH) showed positive correlations with escape and avoidance acceptance. In escape acceptance, a person confronts death as an escape from a physical and psychological pain. When life is full of pain and misery, death may be a welcome alternative. It has been suggested that the fear of living under certain conditions may be stronger than the fear of death (Neimeyer, 1994). A person with a death avoidance view avoids thinking or talking about death in order to reduce death anxiety. In the present samples it seems to be replaced by a defensive response to internal problems.

Table 1 - Relationship between time perspective and death attitude profile

\begin{tabular}{|l|l|c|c|c|c|c|}
\hline \multicolumn{2}{|c|}{ Time Perspective } & $\begin{array}{c}\text { Fear of } \\
\text { death }\end{array}$ & $\begin{array}{c}\text { Escape } \\
\text { acceptance }\end{array}$ & $\begin{array}{c}\text { Natural } \\
\text { acceptance }\end{array}$ & $\begin{array}{c}\text { Approach } \\
\text { acceptance }\end{array}$ & $\begin{array}{c}\text { Death } \\
\text { avoidance }\end{array}$ \\
\hline \multirow{3}{*}{ Past-Negative } & Pearson Correlation & $.399^{* *}$ & $.259^{*}$ & .120 & -.010 & $.221^{*}$ \\
\cline { 2 - 7 } & Sig. (2-tailed) & .000 & .011 & .243 & .922 & .030 \\
\hline \multirow{3}{*}{ Past-Positive } & Pearson Correlation & .043 & .052 & $.252^{*}$ & $.210^{*}$ & -.081 \\
\cline { 2 - 7 } & Sig. (2-tailed) & .678 & .618 & .013 & .041 & .435 \\
\hline \multirow{3}{*}{ Present-Hedonistic } & Pearson Correlation & .152 & $.219^{*}$ & .106 & .162 & $.246^{*}$ \\
\cline { 2 - 8 } & Sig. (2-tailed) & .139 & .032 & .306 & .116 & .016 \\
\hline \multirow{3}{*}{ Present-Fatalistic } & Pearson Correlation & .100 & .088 & $.216^{*}$ & .092 & .151 \\
\cline { 2 - 8 } & Sig. (2-tailed) & .333 & .394 & .035 & .376 & .142 \\
\hline \multirow{2}{*}{ Future Orientation } & Pearson Correlation & .156 & $.214^{*}$ & .191 & $.295^{* *}$ & .025 \\
\cline { 2 - 8 } & Sig. (2-tailed) & .129 & .036 & .062 & .004 & .811 \\
\hline
\end{tabular}

* Correlation is significant at the 0.05 level (2-tailed).

** Correlation is significant at the 0.01 level (2-tailed).

Present-Fatalistic (PF) showed positive correlations with natural acceptance. PF reveals a belief that the future is predestined and uninfluenced by individual actions, whereas the present must be borne with resignation because humans are at the whimsical mercy of "fate" (Zimbardo \& Boyd, 1999). Natural acceptance refers to a view of death as a reality that is neither feared nor welcomed (Neimeyer, 1994). Perhaps the reason for this attitude in the sample is that they accept death as a part of their fate.

Future orientation (F) showed positive correlations with escape and approach acceptance. $\mathrm{F}$ is associated with internal control, planning and a striving for goals and rewards (Kolesovs, 2002; Anagnostopoulo \& Griva, 2011). Future time perspective is associated with it, and leads to a positive outlook on death (Neimeyer et al., 2004). These studies support the relationship between $\mathrm{F}$ and approach acceptance but, quite contrary to previous studies, a positive relation with escape acceptance. Escape acceptance reflects a negative view toward life and a positive view toward death. The researcher can conclude that if a certain time perspective starts to dominate an individual's view of time to the extent that it excludes or minimize the others, it may become dysfunctional (Osin et al., 2009). 


\section{REFERENCES}

Anagnostopoulos, F., \& Griva, F. (2012). Exploring Time Perspective in Greek Young Adults: Validation of the Zimbardo Time Perspective Inventory and Relationships with Mental Health Indicators. Social indicatons research, 106(1) 41-59.

BjornebekK, G., \& GJesme, T. (2009). Motivation and Temporal Distance: Their effect on Cognitive and Affective manifestations. Psychological Reports, 105(2), 339-360.

Fieulaine, F., \& Martinez, F. (July, 2009). Does TP predict influenza vaccination: A longitudinal investigation among French elderly. Oral communication presented at European Congress of Psychology, Norway.

Harrwood I. K., White, I. J., \& Benshoff, J. J. (2008-2009). Death anxiety in a national sample of United States funeral directors and its relationship with death exposure, age, and sex. Omega, 58(2), 129-146.

Hwang, H. L., Chen, T. C., \& Lin, H. S. (2005). Evaluation of life and death studies course on attitude toward life and death among nursing students. The Kaohsiung journal of medical sciences, 21(12), 552-560.

Kolesovs, A. (2002). The relation between time perspective and locus of control in high school students. Baltic journal of psychology, 3(2), 7-19.

Mohammadi, M., Ghorbani, N., \& Abdollahi, A. (2010). The morality salience and self-esteem: an experimental study. Developmental psychology: Iranian psychologists, 7(25), 57-64.

NeImeyer, R. A. (1994). Death anxiety handbook: research, instrumentation, and application. Taylor $\&$ Francis, United Kingdom.

Neimeyer, R. A., Wittkowski, J., \& Moser, R. P. (2004). Psychological research on death attitudes: an overview and evaluation. Death studies, 28, 309-340.

Osin, E., Boniwell, I., Linley, P. A., \& Ivanchenko, G. (June, 2009). Balanced time perspective in Britain and in Russia. Paper presented at the First World Congress on Positive Psychology, Philadelphia, USA.

Sherman, D. W. Norman, R., \& Mcsherry, C. B. (2010). A comparison of death anxiety and quality of life patients with advanced cancer or AIDS and their family caregivers. Journal of the Association of Nurses in AIDS Care, 21(2), 99-112.

Zambianchi, M. \& Ricci Bitti, P. E. (2008). Adopting a systemic-interactionist perspective of human development. Psicologia della Salute, 2, pp.43-62.

Zambianchi, M., Ricci Bitti, P. E., \& Paola, G. (2010). Time Perspective, personal agenda, and adoption of risk behaviors in adolescence. Psicologia Clinica dello Sviluppo. 2, pp: 397-414.

Zimbardo, P. G., \& Boyd, J. N. (1999). Putting time in perspective: A valid, reliable individualdifferences metric. Journal of Personality and Social Psychology, 77(6), 1271-1288.

Zimbardo, P. G., \& Boyd, J. N. (2008). The time paradox. New York: Free Press. 